\title{
キャビテーションジェットに及ぼす噴流ノズル形状の影響
}

\section{Effect of a nozzle shape on cavitation jet}

\author{
正 長谷川 豊（名大）
}

○学 古谷 則生（名大院）正 一菊山 功嗣（名大院）

\begin{abstract}
Yutaka HASEGAWA, Nagoya University
Norio Furuya, Graduate School of Nagoya University

Koji Kikuyama, Graduate School of Nagoya University
\end{abstract}

Key Words : Cavitation Jet, Turbulent Flow, Numerical Analysis, LDV

\section{1. 粕言}

近年キャビテーションジェットを用いた鉄板やデバイス の洗浄が注目され，いくつかの研究が行われている.ノズル によるキャビテーションの発生はジェットによる強い速度 勾配を持つ剪断層と関係しているが, 現象が突発性を伴うこ とならびに気液二相であるためにジェット内部の計測が困 難であり，いまだ十分には解明されていない点が多く残され ており，有効な洗浄法の確立にも至っていない。

本研究は, 佐野らの研究(1)において円形ノズルのノズルス ロート部の長さの違いによりキャビテーション壊食量が著 しく異なる結果に注目し，ノズル形状とキャビテーション発 生との関係を明らかにするための第1 ステップとして, 異な る形状のノズル内部における速度やキャビテーション発生 に関係が深いと思われる速度の乱れ強さをレーザドップラ 流速計 (LDV)により測定を行った。また沉用解析ソフト STAR-CD を用いて, 流れ場の数值解析を行い実験との比較 を行った。

\section{2. 実験装置と方法}

本実験で用いた実験装置の概要を Fig.1 に示す．作動流体 は水である。リザーバタンクの水を渦流ポンプで汲み上げ， ノズルから測定タンク内の水中に水平方向に噴射させる．噴 射された水は水位を一定に保つために設けられた流出口か ら流出し, 再びリザーバタンクに戻る回流式となっている. 本研究で用いるノズルは Fig. 2 に示す 3 種類である。文 ル 1 は円筒形状であり，速度場を計測の検証に用いた。ノズ ル 2，3は佐野らがキャビテーションジェットによる壊食試 験(1)において用いた形状であり，壊食試験の結果，ノズルス ロート部の長さの違いによりキャビテーションジェットの 壊食に大きく影響が及ぶことが分かっている。

LDV は前方散乱差動型で, 光源には He- Ne レーザ $(50 \mathrm{~mW})$ を用いた。また，速度の正負が判別できるよ うに周波数シフ夕を用いた。軸方向，周方向速度測定 に関してはLDV 光学系をトラバースし, 半径方向速度 測定に関してはノズルを上下にトラバースする事によ り測定を行った。

流速測定は, レイノルズ数が単層流下でキャビテーション が発生しない最大值 $4.0 \times 10^{4}$ となるように，ノズルからの噴 出流量を設定した．流量の測定は重量法により計測した。

\section{3. 解析モデルと方法}

解析では軸対称を仮定し，噴流の軸を含む面で半分 を切断した噴流軸周りの方位角で 180 度の計算格子を 用いた。切断面には対称境界を仮定した。モデル形状
は実験装置と異なり，タンク部分が円筒形になってい る。これは全体の計算負荷を低隇させるためであり， このことによる計算結果への影響はほとんどないこと が確認されている。壁面には滑りの無い壁面境界条件 を用いた。メッシュ数は約 23 万点である。乱流モデル は RNG/ $k$-Eモデルを用いている。壁境界では壁関数を 用いているが, 壁面境界層の発達の予測が重要である ノズル部分に関しては，2 層モデルを導入し低レイノ ルズ数型の乱流方程式を使用している。計算は SIMPLE 法による定常計算を行い, 空間離散化は 3 次 差分精度のQUICK 法を用いた。

\section{4. 結言}

三つの異なる形状のノズルを用いて, キャビテーション発 生に強く影響するノズル内の速度及び乱れ強さについて，実 験と計算により以下の結論を得た。

1) 出口端を拡大したノズル 2,3ではノズルの内部に大き な乱れが存在し，ホーン部出口に近づくにつれて全体の 乱れが強くなっていく．特にスロート部の短いノズル 2 ではその傾向がノズル 3 よりも強い.

2）数值解析によって, 速度及び乱れの分布を定性的に再現 することができた。

\section{参考文献}

1) 高橋, 増山, 水中ウォータージェットノズルの性能, 静 岡理工科大学機械工学科卒業論文, (1998).

2) N. ラジャラトナム 原著, 野村安正 訳者, 噴流, 森北 出版, (1981)

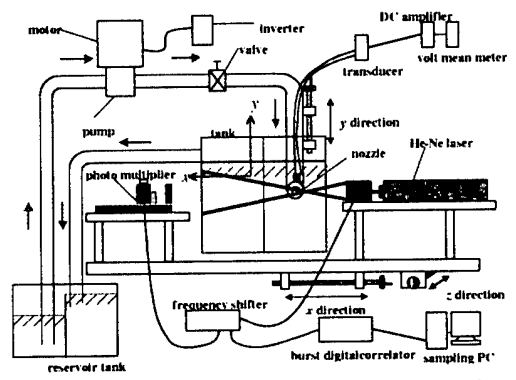

Fig.1 Schematic diagram of experimental equipment

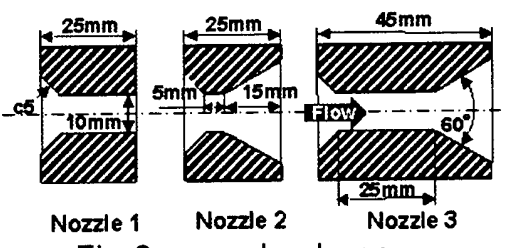

Fig.2 nozzle shape 